IRSH 53 (2008), Supplement, pp. I2 I-I 42 doi:I0.10I7/S0020859008003635 (1) 2008 Internationaal Instituut voor Sociale Geschiedenis

\title{
Brotherhoods and Stock Societies: Guilds in Pre-modern Japan
}

\author{
Mary Louise Nagata
}

\section{INTRODUCTION}

Because the history of guilds is so closely tied to political, economic, and social history, the organizations called guilds tend to vary widely over time and place. In Japanese history there are two organizations with names usually translated as "guild" but which flourished in very different periods and are quite different from each other. Both organizations, though, were associations of people in the same trade or with similar economic interests, and they both took steps to protect and advance the commercial rights of their members by means including attempts to gain monopoly control of certain commodities or markets.

The structure representing guilds in medieval Japan (794-I 573) is the $z a .^{\mathrm{I}}$ $\mathrm{Za}$ literally means "seat" and may refer to a seat in brotherhood meetings of village or shrine, such brotherhoods being one origin of the medieval guild organization, or it could refer to a seat or stall in a market, or a seat at a ceremonial function in honor of a patron. ${ }^{2}$ In cases like that, the seat represented the right to be a member of an organization. Because the term is based on medieval shrine brotherhoods which acted as mediators in village conflicts, I shall refer to the medieval guilds as "brotherhoods" to distinguish za from the early modern organization known as kabu nakama. The distinction is important, because although the $z a$ were abolished when Japan was reunified in the sixteenth century, the early modern Japanese state re-established some $z a$ in the seventeenth century to create and then maintain monopoly control of certain resources, trades, and industries such as silver, silversmiths, and the minting of silver coins. Early modern $z a$ were quite different from kabu nakama, although that term too is translated as "guild".

Although many scholars refer to the kabu nakama as guilds, there is some debate over that definition, some scholars calling them trade associations

I. I am defining medieval Japan as from the beginning of the Heian period to the end of the Muromachi period, the year the last Muromachi shogun was deposed by Oda Nobunaga.

2. Pierre François Souyri, The World Turned Upside Down: Medieval Japanese Society, Käthe Roth (trans.) (New York, 200I), p. 86; Suzanne Gay, The Moneylenders of Late Medieval Kyoto (Honolulu, HA, 200r), p. 57. 
or trade unions. ${ }^{3} \mathrm{Kabu}$ literally means "tree stump", but is also the word used for shares in joint stock companies. Nakama means "members" or "colleagues" in an association or society. Since membership in kabu nakama depended on ownership of kabu, which could be sold, borrowed, traded, inherited, increased, and generally treated like shares of stock, I will call the organizations "stock societies", to avoid confusion between two different coexisting organizations both translated by "guild". It will then be possible to compare their functions in early modern society without seeming to compare guilds with guilds.

The purpose of this study is to discuss the history of guilds in Japan focusing on these two organizations: brotherhoods and stock societies. I will address them chronologically and so will begin with the medieval brotherhoods called $z a$ followed by their early modern transformation, then I shall move on to the kabu nakama which I have called "stock societies", before concluding with a discussion of guilds in Japan.

\section{MEDIEVAL BROTHERHOODS: THE $Z A$}

In 645 , at the conclusion of a series of civil wars, the Japanese court restructured its political and legal system according to that of the contemporary Tang dynasty in China, the most advanced major power of east Asia at that time. Under the new system the state claimed ownership of all land and peasant farmers paid tax in the form of agricultural produce, corvée labor, and service. Many non-agrarian commoners too lived in the mountains or along the coast, and they paid tax in the form of a nonagricultural tribute. The system included periodic redistribution of land based on census enumerations to identify males of productive age who would be liable for both corvée labor and military service, and, for the state, had the advantage of providing regular income, and control over a large standing army. ${ }^{4}$

Because the records were the basis for levies of military service and corvée labor, in the Japanese context they have proved to be rather inaccurate, with many regions recording households consisting of just women, young children, and the elderly. Nevertheless, by using these censuses and tax registers and making a few assumptions, the total population of Japan has been estimated at 4.5 million in 725 , 5.5 million in 800 , and 6.4 million in $900 .^{5}$

3. Ishii Ryōsuke for example, a famous legal historian, uses kumiai to describe the kabu nakama. Kumiai is the word for trade association or union in modern Japanese society; Ishii Ryōsuke, Shōnin [Merchants] (Tokyo, I991), pp. 78-85.

4. Mikiso Hane, Pre-modern Japan: A Historical Survey (Boulder, CO, 1992), p. 33.

5. Kito Hiroshi, Jinko kara yomu Nibon no rekishi [History of Japan through Population] (Tokyo, 2000), pp. 16-17, 53-58. 
The system quite literally divided up all the arable land in Japan with the exception of the capital city and a few of the ports, although very little is known of provincial cities or towns, assuming they existed. Equally little is known of markets or private commerce beyond references to villagers coming to the capital as peddlers.

From the ninth century, during the early medieval period known as the Heian (794-I 180), religious institutions such as shrines and temples and individual members of the nobility who held political power all began to claim private ownership of various lands, so forming complex estates where peasants paid rent to overlords instead of taxes to the state. Gradually the newly emerging warrior class, who themselves often came from the lower ranks of the nobility, took over management of the estates and rent collection, in addition to their official functions as police, lower courts, defense, and tax collection. Eventually, during the Kamakura (I I 80-I 336) and Muromachi (I333-I573) periods, warrior leaders, called daimyo, claimed the estates as their own autonomous domains. ${ }^{6}$

From the eleventh to the thirteenth centuries, groups of commoners who paid non-agricultural tribute to the court also came under the private patronage and protection of various authorities such as religious institutions, the emperor, or individual members of the nobility. Here is an important point: the Chinese court organized trade lines called hang to facilitate tax collection, artisan corvée labor, and procurement of essential goods, which amounted to state control.

In Japan, however, individuals with political authority provided private patronage of these guild-like groups, wherein commoners provided various services and non-agricultural products such as fish, wood, salt, or other things in exchange for exemptions from commercial taxes when they sold these or other goods or services at markets. They were assured of safe conduct allowing them to travel to markets, and of tax-exempt rice land, but such a form of patronage, with the privilege of tax-exempt land, could develop only with the private control of private estates.

Non-agrarian groups frequently called themselves "brotherhoods" partly because many had religious institutions as their patrons. The first appearance of such brotherhoods in the sources is the woodcutters' brotherhood of Yase, north of the capital Kyoto, in 1092. The Yase woodcutters' brotherhood received a license to sell firewood in Kyoto in return for cutting timber for their patron and providing members to bear his palanquin. ${ }^{7}$ Some other

6. Souyri gives a fairly good synthesis of this process in his The World Turned Upside Down, but see too William Wayne Farris, Heavenly Warriors: The Evolution of Japan's Military, 500-I300 (Cambridge, MA, I995), and John W. Hall and Jeffrey P. Mass (eds), Medieval Japan: Essays in Institutional History (Stanford, CA, 1975).

7. A palanquin (kago) is a seat made of bamboo or wood borne on the shoulders of between two and four carriers. 
early brotherhoods include the swordsmiths sponsored by the Todaiji temple in I I 8 and the sake brewers sponsored by the Gempukuji temple in Nara in I $183 .{ }^{8}$

The use of the term $z a$ for these brotherhoods most probably began with the village shrine brotherhoods called miya $z a$, which held meetings in the shrine, to allow open discussion where decisions were made about worship, shrine repair and maintenance, pilgrimages, and to provide a venue where internal community conflicts and problems were addressed and solved. During the thirteenth century, itinerant peddlers, artisans, and merchants formed brotherhoods that paid tribute and provided services in return for commercial rights and protection. People participating in other non-agrarian economic activities did the same thing: performing artists, for example, organized themselves into brotherhoods, taking various shrines and temples as their patrons.

The population of Japan is estimated to have been 6.8 million in I I 50 , after which there are no data at all until 1600 when the estimated population was I $2,273,000 .{ }^{9}$ Of the estimated 7 million in I I 50 , I.4 million are thought to have been living in the Kinai region where the old and new capital cities of Nara and Kyoto were, as well as two ports, Sakai and Hyogo. Another I.6 million lived on the Kanto plain around Kamakura, the political and administrative capital of a newly rising warrior power that established itself in I 80 as the Kamakura regime. The populations of those two political and economic centers comprised around 40 per cent of the total population. ${ }^{10}$

The year I I 50 also happens to be the date of the oldest extant documents recording shops or businesses. During the early medieval period many of the merchants were women and businesses were inherited through the female line. ${ }^{\text {II }}$ Craft products included ceramics, lacquerware, paper, ink, and utensils, or other articles made of bamboo. ${ }^{12}$ Ironically, the earlier centralized imperial organization had a complicated system of overlapping public and private claims to tax and services which obstructed the formation of village communities. The various za brotherhoods were, most probably, substituted as communal organizations. Villages gained a new awareness of themselves as unified communities in the Kamakura period, in opposition to competing multiple and arbitrary outside authorities. ${ }^{13}$

8. Gay, The Moneylenders of Late Medieval Kyoto, pp. 56-6I.

9. Hiroshi, Jinko kara yomu Nibon no rekishi, pp. 16-17, 59-60.

I०. Souyri, The World Turned Upside Down, p. 27.

I I. Takahashi Mitsuo, Taikei Nihon no Rekishi 4: Ōchō no shakai [Japanese History Compendium 4: The Society of the Imperial Court] (Tokyo, 1992), p. I 58.

I2. Ibid., pp. I 50-I74.

I3. Nagahara Keiji, Chüsei nairan ki no shakai to minshu [People and Society during the Medieval Civil War Period] (Tokyo, I977), pp. I 58-187. 
A network of highways, cities, and towns sprang up during that period as local and national economies expanded, until there were twelve major administrative and economic centers under the Kamakura regime: Ishioka, Kamakura, Kumo, Tokiwada, Otsu, Nara, Kyoto, Fukuoka, Omichi, Bofu, Owake, and Hakata. In addition, there were numerous but uncounted local towns labeled $t s u$, ura, shuku, and $i c h i$. Tsu and ura were barely more than large villages with populations of 200-300. Ura were considered towns established to store and market taxable goods and rice. Shuku were post towns with 200-300 households and served as market towns with inns, tea houses, and all sorts of entertainers, with 2,000 or 3,000 people, if we assume an average household of I०. Ichi were quite literally markets, so market towns in effect, often to be found on the banks of rivers. Naturally, many markets were not permanent, but were held only on specific days. Yokkaichi, for example, operated on the fourth, fourteenth, and twentyfourth days of each month of the lunar calendar. ${ }^{\text {I4 }}$

As the warrior class gained ever more control of the agrarian estates, members of the nobility found that a more effective way to demonstrate their political power was to become the patron of a non-agrarian brotherhood, especially a commercial one which would bring together merchants and artisans with similar occupations. Such a course of action would also help noblemen to procure important goods and services.

Brotherhood members paid tax to their patron in return for a license to trade in various markets, preferably with a monopoly on sales in that market or even that whole region, together with exemptions from taxes and tolls and with the right to circulate freely. ${ }^{\text {Is }}$ The patron provided protection against intimidation by other patrons, or brotherhoods, as well as assistance in settling disputes with outsiders. ${ }^{16}$ The ability of the patron to provide such protection represented the political power and status he could command. ${ }^{17}$

While commercial brotherhoods were associations of people trading in the same product or with the same occupation, membership depended more upon having a common patron than being in the same locale. Such kinds of brotherhood could unite members of one occupation in different localities perhaps separated by tens of kilometers, making geographic solidarity difficult. ${ }^{18}$ Moreover, each market was controlled by a separate

\footnotetext{
14. Gomi Fumihiko, Taikei Nihon no Rekishi s: Kamakura to Kyō [Japanese History Compendium 5: Kamakura and Kyoto] (Tokyo, I992), pp. 316-350.

I5. Souyri, The World Turned Upside Down, pp. I53-1 54.

16. Gay, The Moneylenders of Late Medieval Kyoto, pp. 56-6I.

17. Hitomi Tonomura, Community and Commerce in Late Medieval Japan (Stanford, CA, 1982), p. I36. See also Toyoda Takeshi and Sugiyama Hiroshi, "The Growth of Commerce and the Trades", in John W. Hall and Toyoda Takeshi (eds), Japan in the Muromachi Age (Berkeley, CA [etc.], 1977), pp. I29-I44.

18. Gay, The Moneylenders of Late Medieval Kyoto, pp. 56-6r.
} 
political authority and brotherhood rights to a place in a market were specific to that market. So brotherhoods tried to extend their commercial rights to as many markets as possible and to gain monopoly rights in a market if they could, though that was a complex process.

On the other hand, a merchant or a group of merchants from some village, group of villages, or other geographic region might work together to extend their rights for mutual protection and profit. They would join a variety of brotherhoods, since each commodity would have multiple separate brotherhoods and access to each market or even region of markets might be controlled by different political authorities giving privileges to different brotherhoods. Access to markets depended upon the influence of the patrons of the sometimes multiple brotherhoods which members of the group belonged to. For example, the merchants of the Tokuchin estate in Omi province included members of the paper, cloth, salt, and horse brotherhoods. They had the right to trade in a number of markets, each negotiated separately by market and brotherhood. ${ }^{19}$

Some markets had "home" brotherhoods with monopoly rights over certain commodities in that market, but not over other commodities. There were also some large markets that had no home merchants or brotherhoods, and they accommodated outside brotherhoods in a variety of commodities. Brotherhoods that had home markets nevertheless traded at other markets too, so there was often a great deal of competition between brotherhoods trying to gain the right to trade in one or another market or to secure monopoly rights. However, that was not the only area where brotherhoods competed against each other.

Brotherhoods or merchant groups competed for rights to use certain roads leading to other markets. The merchants of the Tokuchin estate, for example, had their goods confiscated by a rival brotherhood on the way to a market the Tokuchin had the right to trade in but had not been to for several years. The other brotherhood claimed that the Tokuchin merchants did not have the right to use the road, but that dispute and others were settled in courts, where the patrons of the various brotherhoods competed to protect and extend the rights of their particular brotherhoods. ${ }^{2 \circ}$ Brotherhoods had to compete for access to raw materials too, with the final goal being to establish a monopsony over any raw material necessary for the production of other commodities. ${ }^{2 \mathrm{I}}$

Thus, merchants competed for access to membership of a variety of brotherhoods while brotherhoods themselves competed with each other

19. Tonomura, Community and Commerce in Late Medieval Japan, pp. 104-106.

20. Ibid., pp. I35-I 38 .

21. Gay, The Moneylenders of Late Medieval Kyoto, pp. 56-61. 
for use of or control over the roads giving access to certain markets. Brotherhoods competed for the right to trade in or even monopolize individual markets, and likewise competed for access to and monopsony control of some resources necessary to the production of their trading commodities. All their rights and privileges depended on having patrons with enough power and influence to guarantee them.

Patrons in turn competed with each other in the same legal and political arena since, during that period of increasing disunity, authority was diffuse and complex. The income of the nobility naturally depended on their own ability to give brotherhoods legal and political protection to ensure their access to markets and to safeguard their privileges, which would in turn attract other brotherhoods keen to have them as patrons. Patrons were in competition with each other, as well as with the clergy, and the growing warrior class.

So it was that brotherhoods did not protect merchants and artisans from the demands of political authorities, but rather political authorities protected brotherhoods from attacks and competition from other brotherhoods, and assisted them in gaining advantages in supply, road access, and market positions vis-à-vis other brotherhoods. In return, patrons gained support in the form of dues and services, as well as the means to establish and improve their political status by providing protection and assistance.

Thus, although guilds are generally thought to reduce market competition, the brotherhoods of medieval Japan changed the nature of competition and broadened its arena. Market competition went far beyond that between individual merchants and artisans who produced and sold the same commodity: instead it included competition between brotherhoods, between merchant groups that joined multiple brotherhoods, and between the patrons of the brotherhoods.

The Muromachi regime of late medieval Japan (I333-I570) never controlled as much of Japan as the Kamakura regime, and, even at its zenith, it was neither as strong nor as stable a political authority as the previous regimes. The daimyo of the Muromachi period were competing with each other and with the political and economic power of major religious institutions such as Todaiji in Nara or Tenryuji in Kyoto.

In some ways, religious institutions had the advantage of firmer control over their branch and regional temples in their respective sects. The Muromachi daimyo were required to live in or near the capital and were forced to leave management of their domains to their vassals, so they were worried about having their domains taken away from them, which happened frequently. Peasants and other villagers often took advantage of the change and the loose control to go on strike and refuse to pay taxes or to allow warrior authority into their communities. The domain lords, instead of supporting their vassal managers against the peasants, actually 
supported the peasants against their own managers. ${ }^{22}$ The brotherhoods were just another player in the political competition.

By the end of the medieval period when decentralization had reached its zenith, the number of occupational brotherhoods, a few dozen by I 200 , had grown to several thousand, particularly as more and more peasants produced more and more commodities for the market and political competition grew stiffer. ${ }^{23}$ In any case, every individual or group wishing to claim political authority at any level, whether daimyo, imperial court noble, old provincial nobility, other provincial authority, clergy, or town council, all used the ability to sponsor a brotherhood and promote its economic interests as evidence of their political power. Moreover, sponsoring a brotherhood gave peasants reasons to ally themselves with a political authority in opposition to any other competitors for their loyalty. The situation became so complex that the declaration of markets as free and open to all comers regardless of brotherhood affiliation became more and more common as a strategy to promote trade and the economic interests of a region, as well as to demonstrate the authority of newcomers to the political game.

The brotherhoods of medieval Japan share some characteristics with the guilds, called sijon, of Korea under the Yi dynasty (I 392-1910), although there were important differences. Yi-dynasty Korea had a highly stable and centralized political system, under which the court established a number of guilds in the capital city giving them license to monopoly rights over their commodities in exchange for regular supply of the same commodities, plus corvée labor. ${ }^{24}$ This organization was related to the old Chinese hang or trade routes, established in the eighth century, ${ }^{25}$ and the Korean sijon were most probably modeled directly on them.

So, the Chinese hang, the Korean sijon, and Japanese $z a$ all provided services and important commodities to their politically important patrons. A comparison of the three could lead one to conclude that such guild-like organizations resulted from the efforts of central authorities to maintain the supply of important commodities and ensure adequate skilled artisan labor.

However, we should not be too quick to leap to conclusions about a general Asian pattern. The ancient Chinese state organized trade routes to facilitate tax collection and the procurement of artisan labor, but otherwise left people alone. The organization was by and for public authority,

22. Nagahara Keiji, Taikei Nihon no rekishi 6: Nairan to minshu no seiki [Japanese History Compendium 6: The Century of Civil War and People] (Tokyo, 1992), pp. 224-225.

23. Ibid.

24. Owen Miller, "Ties of Labour and Ties of Commerce: Corvée Among Seoul Merchants in the Late I9th Century", Journal of the Economic and Social History of the Orient, 50 (2007), pp. $4 \mathrm{I}-7 \mathrm{I}$.

25. See the chapter on Chinese guilds by Christine Moll-Murata in the present volume, pp. $213-246$. 
but included no particular promises of privilege nor monopoly rights. The Japanese organization was a private exercise of political authority and in many ways was a private exchange of goods and services for private privilege, and semi-public political support for mutual benefit and exchange being an important part of the Japanese system. The Korean system developed much later than the other two, contemporaneously with the Japanese late medieval period and continuing through to modern times.

While it had some similarities to both the Chinese and Japanese systems, the Korean system was one of public control of artisan and mercantile activity, on the one hand representing public political control by a centralized state like the Chinese system, but on the other hand implicitly including the exchange of goods and services for mutual benefit. It was more restrictive and controlling than the Chinese or Japanese systems, and unlike the Japanese system, a patron's authority was public and there was no competition among multiple patrons for access to multiple markets. Indeed, the Chinese and Japanese systems each served to promote trade and economic expansion, whereas one goal of the Korean system was to control and limit those.

After the Ōnin Civil War of 1472 that continued as the warring states period (I472-I 568) of late medieval Japan, the political power of individual patrons was not comprehensive and often not really effective. The system came to an end as the new and more powerful daimyo domain lords abolished the brotherhoods to promote the development of commercial activities in their domains, particularly in the castle towns.

Abolishing the brotherhoods served also to remove many of the competitors for political authority. Japan reunified during the latter part of the sixteenth century under the leadership of the warlords Oda Nobunaga, followed by Toyotomi Hideyoshi and finally Tokugawa Ieyasu. During the process of unification, these warlords abolished brotherhoods and monopoly markets to stimulate free trade, a policy continued by the Tokugawa regime throughout most of the seventeenth century, although with some important exceptions. ${ }^{26}$ By doing so, the unifiers established the economic importance of the castle towns as free markets and removed non-agrarian means of economic support from the old nobility. They reduced the political and economic power of religious institutions, thereby establishing themselves as the central economic as well as political authority in unified Japan. ${ }^{27}$

\section{EARLY MODERN BROTHERHOODS: ZA UNDER THE TOKUGAWA REGIME}

The medieval brotherhoods had private and personal relationships with their patrons, who themselves had private power. Brotherhoods competed

26. Gay, The Moneylenders of Late Medieval Kyoto, pp. 56-61, $205-207$.

27. Tonomura, Community and Commerce in Late Medieval Japan, pp. I I-169. 
against each other, and patrons competed against each other and against the public power of the state. During the reunification of Japan in the sixteenth century, abolishing the brotherhoods was a way of denying and then destroying competition from private powers, and served to strengthen the public power of the newly centralized state. At the same time, the unifiers found that control of certain brotherhoods was useful as a way for the state to establish monopoly control of certain important industries. Toyotomi Hideyoshi (I537?-1598), for example, claimed the gold and silver mines for state ownership. ${ }^{28}$

Tokugawa Ieyasu (I542-16I6) continued the policy and he established gold, silver, and copper brotherhoods with the Tokugawa regime (I600I 868) as their patron. Members comprised miners and smelters as well as gold, silver, and coppersmiths. The Sumitomo family was given monopoly control over copper production to regulate the mining and use of this important resource. Establishing brotherhoods was an important step towards the centralization of state control over the economy, in several ways.

During the medieval period, while the economy was increasingly cashbased, the common currency was foreign coins: Chinese silver coins of the Ming or even the Song dynasties, and some Portuguese and Spanish reals and pesos. However, there was not sufficient supply of foreign currency to keep pace with the expansion of the domestic economy during the sixteenth century, so more and more transactions were made in rice. The burgeoning silk textile industry sent much of the foreign currency flowing out of Japan as Japanese merchants imported huge amounts of raw silk from China. ${ }^{29}$

The Tokugawa regime established a new framework for the Japanese economy based on rice, and native currency minted by the government in gold, silver, and copper. Brotherhoods were established for workers of those metals to mint coins to supply a domestic currency, ${ }^{30}$ but Portuguese merchants were exporting I 8,000-22,000 tons of Japanese silver per year, so the Tokugawa regime made it illegal to export silver that was not in the form of currency. There was much smuggling, particularly by the Portuguese, but the Jesuit Society too exported huge amounts of silver in the form of donations. The Nagasaki silver brotherhood was established in I609 to police the outflow of silver and to control the smuggling that was finally halted only when the Portuguese were expelled, foreign trade

28. Kobata Atsushi, "Kōgyō" [Mining], in Kodama Kōta (ed.), Sangyō shi II [Industrial History] (Tokyo, I965), p. I 44.

29. Iwahashi Masaru, "Tokugawa keizai no seido wakugumi” [The Framework of the Tokugawa Economic System], in Hayami Akira and Miyamoto Matao (eds), Keizai shakai no seiritsu, I7th-I 8th seiki [The Development of Economic Society] (Tokyo, I992), pp. 85-I 28.

30. Ibid., pp. I I $4-128$. 
was brought under government control, and Christianity was banned $(\mathrm{I} 635-1639) .{ }^{31}$

Another important move by the Tokugawa government was the establishment of measures brotherhoods in Kyoto and Edo. By the early seventeenth century, measuring cups made of wood or iron manufactured to the sizes standard in Kyoto had already become the de facto standard measures in much of western Japan. In I669, the Tokugawa regime appointed Fukui Sakuzaemon, a master carpenter who manufactured measures in Kyoto, to be the head of a new measures brotherhood in Kyoto. The Edo brotherhood was ordered to harmonize their measures with the Kyoto sizes, and the two brotherhoods were granted monopolies in the manufacture of measures and ordered to use their monopoly to standardize the measures of all Japan.

Since the Tokugawa political system included some 260 semi-autonomous domains, that did not mean that the two brotherhoods had an actual national monopoly on the manufacture and sale of measures, but the heads of the brotherhoods traveled to provinces throughout Japan to inspect the measures there, so as to maintain the standard. At the same time, in spite of monopoly rights, the government used the brotherhoods to suppress prices of the measures. Each new head of the Fukui house, as head of the Kyoto brotherhood, had to swear an oath to maintain the established prices, and the brotherhood could raise prices only with government permission. ${ }^{32}$

In summary, during the process of reunification, the leaders of the newly unified Japan abolished commercial and craft brotherhoods as obstructing commercial market expansion and because brotherhoods supported private political power to rival the public power of the state. Establishing new brotherhoods became useful to the Tokugawa regime to centralize control of certain key industries, to centralize state economic power, and to create the necessary framework for national markets. Those early modern brotherhoods had the state as their patron and were granted monopolies for the purpose of state control rather than for personal profit. That allowed the state to control certain aspects of international trade, the monetary system, and national standards of measurement. In the Tokugawa era, then, the number of brotherhoods was reduced to a few dozen nationwide, a number similar to what we found in the twelfth century when the institution took root.

The new brotherhoods under the Tokugawa regime were similar to Korean guilds of the same period in that they were established by the state. However, the Tokugawa brotherhoods were organs of state economic and

31. Tashiro Kazuo, "Tokugawa jidai no bōeki” [International Trade in the Tokugawa Period], in Akira and Matao, Keizai shakai no seiritsu, I7th-I8th seiki, pp. 129-170.

32. Kyoto City Library for Historical Documents (ed.), Kyō masu za Fukui ke monjo [The Documents of the Fukui Family of the Kyoto Measures Guild] (Kyoto, 200I), pp. 7-16. 
diplomatic policy intended to control important resources for public and state use rather than for private profit, whereas the Korean guilds did not appear to have the same political significance for the Korean court, and represented efforts to control or limit private profit. The Chinese "guilds" of the period were completely different, sharing more characteristics with a separate Japanese guild-like organization, the kabu nakama.

\section{EARLY MODERN STOCK SOCIETIES: THE KABU NAKAMA}

Although the Tokugawa regime abolished brotherhoods of the medieval type with private patrons, the regime did authorize and employ some brotherhoods to establish state control of certain occupations. The regime established or authorized a number of stock societies too in the seventeenth century, and for a similar purpose. For example, the Edo pawnbrokers' society was established in 1642 to control interest rates on loans. Used clothing and equipment (furniture, utensils, for example) societies were established in I645 to police shops and prevent them from becoming outlets for stolen goods. Later, the Edo society of employment agents was established likewise in an attempt to control labor fraud. ${ }^{33}$

These earlier societies tended to be established by government order. The government would establish something called "stock", and ownership of shares in it acted as a license to operate a business in that occupation. One share of stock was a license to operate one shop, manufactory, mill, scale, and so on. One share could represent also the right to buy a specific amount of some raw material available in limited supply but necessary to the operation of the licensed business, such as silk. ${ }^{34}$ So stock represented the commercial activity of a market, and its industry. Stock was defined geographically as well as by occupation and was divided into groups and subgroups so that each had no more than about thirty members, to facilitate the policing of members and the enforcement of prohibitions and contracts.

The number of shares available to a society determined the number of its members. Members could buy more shares and sell or lease them, but the movement of shares outside the geographical region defined by the society was prohibited. So, on the one hand shares represented a license to operate a business and, on the other, the societies had monopoly rights to operate in their specified markets. Theoretically the societies could act as cartels, but the purpose of the Tokugawa regime in establishing or authorizing the societies was to provide for self-policing and enforcement of legal restrictions, as well

33. Yunoki Manabu, Sake zukuri no rekishi [History of Sake Brewing] (Tokyo, I987), p. 48. 34. Miyamoto Mataji, Kabu nakama no kenkyū [Research on Kabu Nakama] (1938, 3 rd edn, Tokyo, 1970), pp. 36-37; Tetsuji Okazaki, Edo no shijo keizai: Rekishi seido bunseki kara mita kabu nakama [The Market Economy of the Edo Period: Kabu Nakama seen from Analysis of the Historical System] (Tokyo, I999), pp. 86-87. 
as to control prices, ${ }^{35}$ two functions particularly important in a society that urbanized quite rapidly while developing commercial and manufacturing networks encompassing rural villages as well as cities and towns.

One of the unification policies in the late sixteenth and early seventeenth centuries was the removal of the warrior class, with their access to direct support, from their rural villages to castle towns and cities. Warriors were given the choice of giving up the sword to keep their land, or giving up their land and moving into their lord's castle town to keep their sword and their warrior status. In addition, the domain lords, the daimyo, were required to maintain their main residences in the capital, Edo.

A consequence of the policy was rapid urbanization. Although the number of domains varied as new ones were created and others confiscated, the Tokugawa period averaged around 260 domains at any time. Each domain could have a castle town, and by 1650 there were 250 castle towns of varying sizes with 25 of them cities, having populations of 30,000 or more. ${ }^{36}$ The warrior class by itself accounted for around 8 per cent of the population then. Adding the populations of the castle towns to the three metropolises - Edo, Osaka, and Kyoto - plus other commercial cities in the Kinai region (roughly including Kyoto, Osaka, Nara, Sakai, and Fushimi) gives an urban population in 1650 of around is per cent of the total population, estimated at $\mathrm{I} 2.3$ million. ${ }^{37}$

There is an ongoing debate about the degree to which Tokugawa society was urban. There is no doubt that hundreds of communities grew to become commercial, industrial, and post towns during the eighteenth and nineteenth centuries, yet calculations based on late nineteenth-century censuses estimate that only around I 6 per cent of the Tokugawa population resided in cities of 3,000 or more in spite of the evidence of growing urbanization. ${ }^{3}$ The calculation is complicated by the fact that records of the populations of many of the largest cities are missing after the mideighteenth century, and other communities with populations of 2,000 to 3,000 continued to be regarded as villages, even when they functioned as important regional towns or ports. ${ }^{39}$ As a rough guide, the I 886 census,

35. Yagi Tetsuo, "Kinsei no shōkōgyōsha to toshi" [Early Modern Commercial Crafts and Cities], in Nakamura Yoshinao (ed.), Shakai shi II [Social History] (Tokyo, I982), pp. I69-172. 36. Nakai Nobuhiko and James L. McClain, "Commercial Change and Urban Growth in Early Modern Japan”, in John Whitney Hall and James L. McClain (eds), The Cambridge History of Japan, IV: Early Modern Japan (Cambridge, 1991), pp. 519-595.

37. Shinbo Hiroshi and Hasegawa Akira, "Shōhin seisan, ryūtsū no dainamikkusu" [The Dynamics of Commodity Production and Distribution], in Akira and Matao, Keizai shakai no seiritsu, $I 7-18$ seiki, pp. $217-270$.

38. Gilbert Rozman, "Castle Towns in Transition", in Marius Jansen and Gilbert Rozman (eds), Japan in Transition: From Tokugawa to Meiji (Princeton, NJ, 1986), pp. 318-346.

39. Hamano Kiyoshi, Kinsei Kyoto no rekishi jinko gaku teki kenkyū [Historical Demographic Research on Early Modern Kyoto] (Tokyo, 2007), p. 29. 
although it had many flaws, records 333 cities with populations of 3,000 or more. ${ }^{40}$

The sake-brewing industry is one example of a society established by the state as a licensing mechanism where membership (i.e. stock ownership) was required to operate a business, although of course the establishment of the licensing mechanism does not indicate the beginning of the brewing industry, which had existed for centuries. Indeed, in a previous section I mentioned the sake brewers of Nara, for example, who established a brotherhood in II $83 .{ }^{4 \mathrm{I}}$

Rice was a core feature of the Tokugawa economic system and could act as a substitute for cash, so for that reason sake brewing particularly concerned the Tokugawa regime, since distribution and trade in rice affected the price of it and so had direct consequences for the national economy. Controlling the amount of rice used by the brewing industry was, therefore, one important reason the regime established brewing stock in I660 and required ownership of shares as a license to brew. The stock certificate showing ownership of shares of brewing stock was a wooden plaque recording the volume of different kinds of rice the brewer was allowed to use each year for brewing. The license further defined where the business could operate according to province, district, and village or city. The amounts and types of rice the brewer had license to use made up his share of the brewing stock, while the location defined which brewing society he belonged to. The standard shares licensed the brewer to brew and sell his sake only in the local markets. The rice could be polished white rice, unpolished brown rice, or unhulled rice. ${ }^{42}$

Any firm could own stock in multiple societies in both villages and cities, thereby increasing the potential overall volume of its business. The Konishi sake breweries, for example, had their main business and brewery in the village of Itami outside Osaka, but had branches in Osaka and Edo, so they owned stock in those markets as well. ${ }^{43}$ Stock societies were clearly not limited to the cities, as many of the important firms and their production were located in rural villages. Tondabayashi, a "village" established as a temple and market town in the sixteenth century, had stock societies for brewing sake and for manufacturing

40. Rozman, "Castle Towns in Transition", p. 323. One of the major flaws in the I 886 census is that it records the de jure rather than the de facto population, thus underestimating the urban population and overestimating the rural population.

4I. For example, in medieval Kyoto the brewing and sale of sake was an important activity, employing mainly women; Gay, The Moneylenders of Late Medieval Kyoto, pp. 56-6I.

42. Manabu, Sake zukuri no rekishi, pp. 47-48.

43. Mary Louise Nagata, Labor Contracts and Labor Relations in Early Modern Central Japan (London [etc.], 2005), pp. 26-30; Yunoki Manabu, "Kinsei Itami shuzō gyō no tenkai to Konishi ke" [Developments in the Sake-Brewing Industry of Early Modern Itami and the Konishi Family], Chiiki Kenkyū Itami, I8 (1989), pp. I-23. 
cotton textiles, both of which were established during the seventeenth century. ${ }^{44}$

Members could not sell or lease shares to brewers outside the defined region. Of course, that meant prohibitions against unlicensed brewing, which were enforced by confiscating brewing equipment. Society members therefore had a monopoly on brewing for their particular market, but membership meant both a license to brew and limitations on how much and where they could brew, and then sell.

There were other kinds of brewing stock. Sake shipped to the Edo market, for example, was yet another part of the brewing stock available to members of certain societies, with shares available for a price and separate from local market shares, which allowed for both access to more rice and the production of greater volume. Unlike the local shares, Edo export shares could be sold or traded outside the region or market of the original license. ${ }^{45}$

Although the state established certain stock societies for government convenience, formation of unregulated commercial stock societies was banned in 1657. Nevertheless, in the Genroku era (I688-1704), ten Edo wholesalers formed a society on their own initiative for the purpose of establishing coastal shipping circuits and addressing maritime shipping problems, in the face of losses from pirates. In their activities, the society members pooled their investment in ships and shipping. The society did not receive state recognition at first, but in the early eighteenth century the Tokugawa regime came to authorize such societies and even promoted them.

In I7 I 5 , the state ordered wholesalers to form stock societies to control the coinage then in circulation. In spite of the silver brotherhoods, silver had remained a problem, continuing to flow out of Japan via international trade, particularly due to the high demand for raw silk. Under the shogun Tsunayoshi (I680-I709), the regime fiddled with the quality of the silver used for coinage, changing it several times, which resulted in great confusion in the market about the actual value of coins, as well as causing price inflation. After Tsunayoshi's death, there were efforts to bring the economy back under control and the authorization and requirement for wholesalers' stock societies was a way to control what coins were in circulation. Stock societies were useful too when the eighth shogun, Yoshimune, instituted controls to hold down prices in $172 \mathrm{I}$ as part of his Kyōhō reforms. At that time, far from discouraging stock societies, merchants, artisans, and manufacturers in various occupations were required to form and join stock societies. ${ }^{46}$

44. Nagata, Labor Contracts and Labor Relations in Early Modern Central Japan, pp. 48-49; Fukuyama Akira, "Kinsei Kawachi shuzō gyō no tenkai" [Development of the Brewing Industry in Early Modern Kawachi], Tondabayashi Shi Shi Kenkyū Kiyō, 5 (1976), pp. I-57.

45. Manabu, Sake zukuri no rekishi, pp. 49-53.

46. Ryōsuke, Shōnin, pp. 78-85; Masaru, “Tokugawa keizai no seido wakugumi”, pp. I I4-I 28. 
One other way stock societies were convenient for the state was that they policed themselves. The regulations of most societies included a clause stating that if one member violated a contract or cheated, the other members should not do business with him. Similar exclusions were applied to customers, suppliers, or other business partners dealt with by members. Another regulation was an agreement that no member would hire any employee fired by another member for misconduct. Moreover, a former employee could join the society as a fully fledged member only if his former employer introduced him.

Regulations like that served as mechanisms to enforce contracts and control misconduct, cheating, and other corruption in the commerce of a society with both national markets and a decentralized political and legal system. ${ }^{47}$

For example, the Nishijin silk brokers formed a stock society in the early eighteenth century for buying raw silk. The society agreed the years a skilled worker had to work before he would be accepted as independent, and various other membership rules and a requirement for supervision of the skill level of adopted sons. At the same time, members agreed upon expulsion as punishment for causing loss or damage to another member's business, and they undertook to report on deals outside the society and not pretend unilaterally to represent the society, nor to take on new customers who had unpaid bills with other members. ${ }^{48}$

Although societies had their own hierarchy of officers, they were in many ways egalitarian organizations and that is partly why the policing functions worked. It is a particularly interesting characteristic, since merchant federations, formed on the stem and branch framework of a stem-family lineage, were hierarchical. A family firm would expand by establishing a branch managed by a younger son, a son-in-law, or a management employee, and branches were typically subordinate to the stem. The combination of the stem firm and all its branches and sub-branches comprised a merchant federation. ${ }^{49}$

Many a society, however, had both stem and branch members of a federation as equal members of the society, thereby allowing the branch to act independently and facilitating the independence of the branch business. A society was a kind of community, the communal aspects becoming as important to members as the economic ones. A society provided insurance and assistance to its members, had its own festivals and ceremonies, and

47. Miyamoto Mataji, Kabu nakama no kenkyū [Research on Kabu Nakama] (Tokyo, I938); Okazaki, Edo no shijō keizai.

48. Tetsuo, "Kinsei no shōkōgyōsha to toshi", p. i78.

49. Nakano Takashi, Shōka dōzoku dan no kenkyū [Research on Merchant Houses and Federations] (Tokyo, I978), I, pp. 5-6; Nagata, Labor Contracts and Labor Relations in Early Modern Central Japan, pp. 23-30. 
members even went on tours and enjoyed other leisure activities together. ${ }^{50}$ In such functions for mutual benefit the stock societies were similar to the later Chinese organizations, and to European guilds. ${ }^{5 \mathrm{I}}$

Since membership of a stock society was effectively a license to participate in a specific market and could also limit its membership, stock societies became the vehicle for achieving and protecting monopoly rights, and some groups formed their own commercial stock societies hoping to establish monopoly rights and keep non-members out of their market. One example of such an attempt is the Kyoto soy sauce brewers' society.

In 1755 , the soy sauce brewers of Kyoto requested permission from the city government to form a stock society for the purpose of "clearing up confusion in the market" as there were no standard units of measure used in the sale of soy sauce, nor standards for pricing. The soy sauce brewers wanted to prevent any single brewer or group of brewers from buying up and stockpiling the supplies necessary for brewing soy sauce. ${ }^{52}$ No restrictions were placed on joining the society, nor on the number of shares available, except that if a former employee of any member wished to join he had to be introduced by that member.

The Kyoto soy sauce brewers' society had 176 members and was subdivided into 3 large groups, each further subdivided into between 4 and 7 smaller groups. A month later, the society requested permission to exclude brewers from outside Kyoto, and received it, giving the local brewers their monopoly protection. The exclusion was granted, but never successfully enforced. Brewers from Bizen province had already been exporting soy sauce to Kyoto for a number of years and merchants and manufacturers of various commodities in Bizen had been exporting to Kyoto since $1606 . .^{53}$

The Kyoto brewers complained that brewers from outside were selling directly to retailers and the public, bypassing the wholesalers and brokers whom the Kyoto brewers used. In response, the Bizen soy sauce wholesalers in Kyoto organized their own stock society, and later there was some attempt to absorb them into the local brewers' society, but they refused to join. At the same time, other brewers in Harima, Osaka, Omi,

50. Tetsuo, "Kinsei no shōkōgyōsha to toshi”, pp. I69-172.

5I. See the article by Christine Moll-Murata in the present volume (pp. 213-247).

52. Kyoto, as one of the three metropolises of the Tokugawa polity, was under the direct administrative control of the central government, represented by two city magistrates and a treasury magistrate. Kyoto townsmen also had a council that addressed and controlled most civil and economic matters, but the council was answerable to the magistrates; Akiyama Kunizō, Kinsei Kyōto machi gumi hattatsu shi [The History of the Development of Early Modern Kyoto Neighborhood Groups] (Tokyo, I980); Kamada Michitaka, Kinsei Kyōto no toshi to minshu $\bar{u}$ [The City and People of Early Modern Kyoto] (Kyoto, 2000), pp. 343, 353. 53. Fujita Akinori, Kyoto no kabu nakama: sono jissho teki kenkyū [The Kabu Nakama of Kyoto: Case Studies] (Kyoto, 1987), pp. 2-43. 
and Sakai exported soy sauce to Kyoto and likewise sold directly to retailers and the public. The wholesalers from outside then formed the outside soy sauce brewers society in $177^{2}$.

After a major fire in 1788 , the Kyoto city government dissolved all local professional societies and licensing requirements were cancelled for a while to restart the economy. ${ }^{54}$ When the societies re-formed in the early nineteenth century, a new requirement was added of one wholesaler and one retail shop for each brewery. At no time did the local brewers' society succeed in preventing non-members from operating in the Kyoto market, and by the early nineteenth century the outside wholesalers representing major regional brewing industries actually dominated the Kyoto market by offering better quality at lower prices. ${ }^{55}$ So, there we have an example of a stock society formed to establish and protect monopoly rights, but unable to enforce them successfully. One factor in their difficulty was that daimyo of domains exporting soy sauce to Kyoto exerted pressure to allow wholesalers to sell without joining the society. ${ }^{56}$ Apparently, monopoly rights were not so easy to establish and then enforce, even in the presence of a stock society.

During the latter half of the eighteenth century the Tokugawa regime required stock societies participating in the national market to pay dues and taxes to the state. The regime also pressed more and more occupations to form stock societies and promoted the expansion of their membership in an effort to increase production and commerce. The ro-group wholesalers' society authorized for Edo in the early eighteenth century, for example, expanded to 65 groups with I,995 shares of stock by the nineteenth century. The policy provided commercial revenue for the state while it could use the stock societies to enforce contracts and maintain the commercial infrastructure.

The stock societies were expected to hold prices down, although many people suspected them of using their monopolies to keep them high. Under that belief, the stock societies were abolished in I84I on the assumption that prices would be reduced as a result. The consequences, however, were general confusion in the market and price inflation. So the stock societies seem to have been quite successful as a mechanism for government control of the market. 57

In summary, for two centuries from I640 to I84I stock societies acted as licensing mechanisms with membership representing, at the very least,

54. Ibid.

55. Hasegawa Akira, Kinsei tokusanbutsu ryūtsu shi ron: Tatsuno shōyu to bakuhansei shijō [Essay on the History of the Circulation of Early Modern Speciality Products: Tatsuno Soy Sauce and the Market under the Shogunate System] (Tokyo, 1993).

56. Akinori, Kyoto no kabu nakama, pp. 2-43.

57. Ryōsuke, Shōnin, pp. 78-85. 
a license to operate a business in a specific market. Membership was defined as ownership of shares of stock and societies had various rules about who could become a member, with the rules as the effective qualification for a license. Membership could be limited either to a specific number of members or unlimited apart from the entrance qualifications. When shares were limited, stock societies could become monopoly associations with monopoly control of a market, but that was neither easy nor always possible.

While stock societies could be formed of their own accord by cooperation of members, many societies were established by the state, with compulsory membership. The state used stock societies to monitor the market, using peer pressure and commercial or economic pressure to enforce contracts and to police cheating or other criminal activities. The state also used stock societies to micromanage the economy with regard to the money supply, the coinage in circulation, interest rates on loans, the amount of rice absorbed by sake brewing, international trade, suppression of prices, and other concerns.

In the eighteenth century the state found the dues and taxes paid by stock societies to be a convenient source of revenue, but that concern was probably secondary to their policing and economic management functions. The stock societies, therefore, provided trust and regulation necessary in a rapidly growing national market set in a decentralized political and legal environment.

\section{BROTHERHOODS AND STOCK SOCIETIES AS GUILDS: A CONCLUDING DISCUSSION}

I have briefly examined the histories of two organizations frequently identified in the research literature as guilds and which flourished in two different periods of Japanese history. The two organizations were rather different from each other, with early modern brotherhoods somewhat different again from medieval ones. In this section I shall compare those organizations with the general characteristics of medieval European guilds.

I began this article with a working definition of a guild, as an association of people with the same trade or similar economic interests that takes steps to protect and advance the commercial rights of its members. It is a definition which fits both brotherhoods and stock societies, as well as a great many other groups, including trade and labor unions, trade associations, and even consumer protection groups.

Now I will add a number of general characteristics of medieval European guilds for comparison with the two Japanese organizations, $z a$ and $k a b u$ nakama, that have been the focus of this study. Scholars describing those organizations as guilds usually have in mind European guilds, and for convenience I have used the description in Gary Richardson's article 
"Medieval Guilds" in the EH.Net Encyclopedia. ${ }^{8}{ }^{8}$ For the purpose of this discussion, I will call the guilds of medieval Europe "European guilds" and continue to call the other two organizations "brotherhoods" and "stock societies".

One important characteristic of European guilds is contract enforcement, both among members, and between members and outsiders. Contract enforcement and policing of members was certainly one of the main functions required of stock societies by the Tokugawa state, but the reason for the enforcement was not necessarily the community responsibility system as claimed for guilds, although Tokugawa society too institutionalized community responsibility in its social system. The medieval brotherhoods, however, were far more dependent upon their patrons' ability to manipulate the courts, although certainly one function of medieval brotherhoods was to address conflicts and settle disputes between members. But that function was required too of non-commercial brotherhoods and village communities.

European guilds protected their members from political authorities in other countries who might try to seize money or merchandise from foreign merchants as an easy source of income. The danger of attack and seizure of goods in medieval Japan, however, came from other brotherhoods, since that was one method brotherhoods used to defend or extend their commercial rights and privileges.

Disputes were ultimately fought out in the courts between patrons of brotherhoods, so rather than a brotherhood protecting its members from predation by political authorities, their patrons as political authorities protected the brotherhoods against other brotherhoods, who would have been sponsored by competing political authorities. Since Japan was far more centralized under the Tokugawa regime than during the medieval period, the only risk of predation was from pirates and bandits, and the legal and political authority of the state had ultimate responsibility for protection. Indeed, the contract enforcement and policing aspects of the stock societies were part of the mechanism of legal protection.

Some European guilds were known to have unusual influence on local governments, but in Japan neither brotherhoods nor stock societies had much direct political influence as independent agents. If anything, the reverse was true, particularly under the Tokugawa regime where the state used somewhat inordinate influence to make the brotherhoods and societies manage the economy. However, one could argue that the medieval brotherhoods themselves, with their competing patrons, represented expressions of political influence. 
Like the European guilds, medieval Japanese brotherhoods tried to manipulate input and output markets to their own advantage, establishing both monopoly rights in markets and monopsonies of raw materials if possible. These practices were one factor behind the abolition of brotherhoods and the establishment of "free markets" during the sixteenth century. Under the Tokugawa regime (I600-I868), the state used stock societies to limit and manage access to input and output markets as part of its management of the economy. Moreover, stock societies were more likely to establish reputations for quality, another strategy used by European guilds. Stock societies had the chance of monopoly control of specific markets, but that was not always easy to enforce. Monopoly control usually suggests high prices, but one reason the state began to promote them was to suppress prices, so that some societies at least had to apply for permission to raise them. The dramatic price rises after stock societies were abolished in $\mathrm{I} 84 \mathrm{I}$ is usually thought to prove the effectiveness of the state's strategy to suppress prices.

Little is known about the labor market during the medieval period of Japanese history, but labor included some combination of free and unfree labor as well as indentured labor. Stock societies during the Tokugawa period certainly tried to manage labor markets, especially to control the human capital in skilled labor. However, commercial expansion from at least the latter part of the eighteenth century made labor a seller's market and the stock societies were more concerned with finding and maintaining a supply of labor than with causing wages to fall. 59

Brotherhoods and stock societies share certain characteristics with European guilds. Those characteristics do not always overlap with each other, but are likely to be behind the interpretation of these organizations as being guilds. Nevertheless, the Japanese organizations differ from European guilds in very important ways, particularly in their relation to political authority. Indeed, the main characteristic that brotherhoods share with European guilds is the attempt to manipulate markets to establish monopoly control of both the commodity and the resources necessary to produce it.

Even the matter of mutual protection was aimed at other brotherhoods rather than political authorities. The stock societies also shared important characteristics with European guilds in their enforcement of contracts. However, stock societies were important agents of state management of the economy rather than acting against it. In the end, one major difference in the Japanese groups called "guilds" is their alliance with and support for political authorities and state power.

In that light, can we call them guilds? Perhaps we should understand them as an alternative way of addressing many of the same issues that European guilds addressed. 
Indeed, this one difference generally extends to China and Korea too. Asian guild organizations tended to have positive and cooperative rather than antagonistic relations with political authority, and Asian political authority found guild structures quite useful for tax collection and artisan labor supply. Yet, is that a difference in the guild organization itself, or a difference in political and economic attitudes? European political authority could at times just as well ally itself with or make use of guilds, so is the difference really so critical, and is there enough to make claims for a specifically Asian pattern?

A second characteristic common to all the Asian organizations, but different from European guilds, is membership. Asian organizations were essentially commercial associations of business owners rather than individual artisans. One could not become a member unless one operated a business, and membership tended to be a business license. European guilds, however, were generally artisan and trade associations whose members included, as well as masters, apprentices and journeymen who might have been employed by others rather than operating their own businesses. That might seem a minor difference, but it is important. Where guilds in both Europe and Asia might well have been concerned with quality control, in Asia that meant a business had to employ skilled artisans rather than requiring that individual guild members had the required skills.

On the other hand, those similarities aside, Asian guilds were quite different from each other in how much control political authorities exerted, and in how much freedom they enjoyed to operate businesses and make profit. Asian guilds reduced competition in some places and increased it in others. Political authorities could require businesses to join guilds, or they might view guilds with suspicion. Guilds could form spontaneously and then be either acknowledged or ignored by political authorities, or political authorities themselves could organize them. The relationship between political authority and guild organizations could be either public or private and could be one of regulation, or of mutual political and economic exchange.

With all these differences, can we really say that there is an Asian pattern or should we say simply that the European organizations are guilds, but the Asian ones are business associations? European guilds too were quite diverse and operated in changing political, economic, and social environments. If we recognize the Asian associations as similar enough to European ones to call them all "guilds", then perhaps we should not emphasize the contrast between East and West, but focus on the functional needs that guilds fulfilled and ask about the various ways in which societies answered them. 